\title{
PENGARUH LITERASI KEUANGAN TERHADAP INKLUSI KEUANGAN MELALUI FINANCIAL TECHNOLOGY PADA UMKM DI BANDAR LAMPUNG
}

\author{
I Nyoman Patra Kusuma \\ Program Studi Magister Manajemen Universitas Tarumanagara \\ inyo88man@yahoo.co.id
}

Masuk : 07-12-2019, revisi : 21-12-2019 diterima untuk diterbitkan : 21-12-2019

\begin{abstract}
The presence of financial inclusion can overcome various causes, one of which is to overcome the low financial literacy in Indonesia. Financial knowledge and skills in managing personal finances are very important for daily life. Many people in the city of Bandar Lampung began to dare to make efforts to help the family economy. The types of businesses opened are many in the fields of food and fashion. This study aims to determine the effect of financial literacy on financial inclusion, financial literacy on financial technology and financial technology on financial inclusion at UMKM in Bandar Lampung. The number of samples used was one hundred respondents using a purposive sampling method. The results of the analysis use Smart PLS V.03. The results of this study have the implication that with good financial literacy, it is expected that UMKM will be able to make the right management and financial decisions to improve business performance and sustainability. In addition, UMKM in Bandar Lampung can use financial technology products that are under the supervision of the OJK in order to avoid the many cases of fraud that occur.
\end{abstract}

Keywords : Financial Literacy, Financial Technology, Financial Inclusion

Abstrak : Hadirnya inklusi keuangan dapat mengatasi berbagai penyebab salah satunya mengatasi rendahnya literasi keuangan di Indonesia. Pengetahuan keuangan dan keterampilan dalam mengelola keuangan pribadi sangat penting bagi kehidupan sehari-hari. Banyak masyarakat di Kota Bandar Lampung yang mulai berani melakukan usaha untuk membantu perekonomian keluarga. Jenis usaha yang dibuka yaitu banyak dalam bidang makanan dan fashion. Penelitian ini bertujuan untuk mengetahui pengaruh literasi keuangan terhadap inklusi keuangan, literasi keuangan terhadap financial technology dan financial technology terhadap inklusi keuangan pada UMKM di Bandar Lampung. Jumlah sampel yang digunakan sebanyak seratus orang responden dengan menggunakan metode purposive sampling. Hasil analisis menggunakan Smart PLS V.03. Hasil penelitian ini memiliki implikasi bahwa dengan literasi keuangan yang baik diharapkan UMKM akan mampu membuat keputusan manajemen dan keuangan yang tepat untuk peningkatan kinerja dan keberlanjutan usaha. Selain itu UMKM di Bandar Lampung dapat menggunakan produk financial technology yang berada di pengawasan OJK agar menghindari banyaknya kasus penipuan yang terjadi.

Kata Kunci : Literasi Keuangan, Financial Technology, Inklusi Keuangan

\section{Pendahuluan}

Global Financial Development Report (2014) mendefinisikan Financial Inclusion sebagai suatu keadaan di mana mayoritas individu dapat memanfaatkan jasa keuangan yang tersedia serta meminimalisir adanya kelompok individu yang belum sadar akan manfaat akses keuangan melalui akses yang telah tersedia tanpa biaya yang tinggi. Survei Nasional Literasi Keuangan dan Inklusi Keuangan (SNLIK) Indonesia yang dilakukan Otoritas Jasa Keuangan (OJK). Berikut data literasi keuangan dan inklusi keuangan pada berbagai industri keuangan di Indonesia pada tahun 2018: 


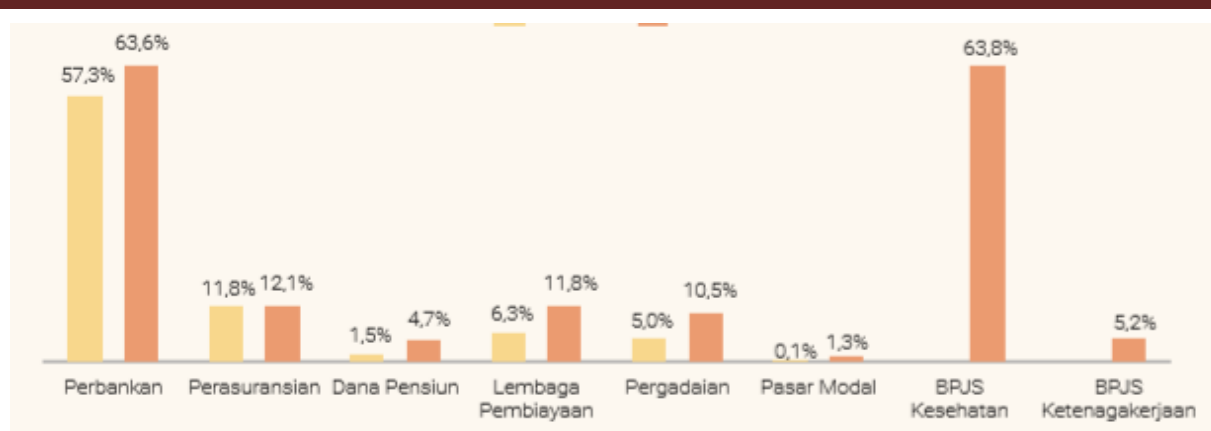

Sumber : Survei Nasional Literasi dan Inklusi Keuangan,OJK 2018)

Gambar 1

Grafik Tingkat Literasi dan Tingkat Inklusi Berbagai Industri Keuangan di Indonesia Tahun 2018

Gambar 1 menunjukkan bahwa industri perbankan memiliki tingkat literasi keuangan dan inklusi keuangan paling tinggi diantara industri keuangan yang lain yaitu sebesar 57,3\% dan $63,6 \%$, dan industri pasar modal menempati urutan terendah yaitu sebesar $0,1 \%$ dan $1,3 \%$. Dapat disimpulkan bahwa penggunaan produk keuangan di Indonesia masih belum merata pada setiap sektor jasa keuangan. Forum organization for economic co-operation development (OECD) menetapkan bahwa untuk memperkuat sistem keuangan dan meningkatkan kesejahteraan masyarakat diperlukan integrasi antara inklusi keuangan, literasi keuangan dan perlindungan konsumen. Hadirnya inklusi keuangan dapat mengatasi berbagai penyebab salah satunya mengatasi rendahnya literasi keuangan di Indonesia. Salah satu kecerdasan yang harus dimiliki oleh manusia modern adalah kecerdasan finansial, yaitu kecerdasan dalam mengelola aset keuangan pribadi. Pengetahuan keuangan dan keterampilan dalam mengelola keuangan pribadi sangat penting bagi kehidupan sehari-hari. Literasi keuangan (Financial Literacy) merupakan suatu keharusan bagi tiap individu agar terhindar dari masalah keuangan karena individu seringkali dihadapkan pada trade off yaitu situasi dimana seseorang harus mengorbankan salah satu kepentingan demi kepentingan lainnya. Dengan menerapkan cara pengelolaan keuangan yang benar, maka individu diharapkan bisa mendapatkan manfaat yang maksimal dari uang yang dimilikinya (Lia dan Nurdin,2019).

Di Indonesia, era digital ditandai dengan meningkatnya penggunaan internet oleh masyarakat. Menurut data tahun 2018 dari Global Digital Report Data, jumlah pengguna internet di Indonesia telah mencapai 132 juta orang, atau lebih dari 50\% masyarakat Indonesia dapat mengakses internet. Oleh karena itu, saat ini, aktivitas masyarakat modern cenderung menggunakan teknologi lebih intensif untuk memenuhi kebutuhannya. Sudah menjadi kebiasaan masyarakat saat ini, ketika melakukan kegiatan sehari-hari menggunakan teknologi, seperti membeli makanan, memesan transportasi, mengirim barang, memesan tiket, dan berbisnis. Karena adanya teknologi, manusia merasa kegiatan mereka menjadi lebih terbantu dan lebih efisien (Rahman \& Salam, 2018).

Fintech merupakan istilah yang populer dalam beberapa tahun terakhir ini. Ketika seseorang mendengar istilah fintech, maka yang terlintas dalam pikirannya adalah segala kemudahan dan kecepatan dalam transaksi keuangan, seperti kemudahan dan kecepatan dalam pembayaran, peminjaman, pengiriman, dan sebagainya. Dengan fintech diharapkan dapat menghemat waktu, pikiran, tenaga, dan biaya. Fintech merupakan layanan inovatif di bidang keuangan yang menggunakan atau memanfaatkan peran teknologi (Rahman \& Salam, 2018). Pada hakikatnya, fintech adalah layanan keuangan berbasis teknologi. Pembayaran tagihan listrik, cicilan kendaraan, atau premi asuransi secara online adalah beberapa contoh produk fintech yang sering digunakan dalam keseharian, demikian juga dengan pengiriman uang atau pengecekan saldo melalui online banking.

Banyak masyarakat di Kota Bandar Lampung yang mulai berani melakukan usaha untuk membantu perekonomian keluarga. Sifatnya adalah memulai usaha baru maka para masyarakat 
ini cenderung untuk memilih usaha berskala mikro. Jenis usaha yang dibuka yaitu banyak dalam bidang makanan dan fashion. Dinas Koperasi, UKM. Perindustrian dan Perdagangan Kota Bandar Lampung mencatat jumlah UMKM sebanyak 3196 unit. Usaha mikro terdapat 2125 unit dan usaha kecil terdapat sebanyak 886 unit sedangkan pada usaha menengah jumlahnya lebih sedikit yaitu sebanyak 185 unit. UMKM tersebut tersebar di 20 kecamatan yang ada di kota Bandar Lampung.

Penelitian ini akan menganalisis penggunaan fintech di Indonesia khususnya sebagai metode pembayaran pada UMKM di kota Bandar Lampung dan sekitarnya dengan kriteria usaha "kecil" sesuai dengan UU No. 20 Tahun 2008, yaitu kriteria usaha yang memiliki aset Rp 50.000.000 sampai dengan Rp 500.000.000 tidak temasuk tanah dan bangunan tempat usaha, dan memiliki omset tahunan Rp 300.000.000 sampai Rp 2.500.000.000. Kriteria "kecil" ini dipilih karena banyak fenomena yang terjadi, usaha masih dalam tahap pengembangan, belum terlalu matang dalam memiliki sifat kewirausahaan sehingga dapat dilihat margin atau perbedaannya antara usaha yang menerapkan fintech atau tidak. Tidak diperhatikannya layanan ini, maka dapat menimbulkan tidak berkembangnya bisnis suatu UMKM yang dapat mengakibatkan tidak berhasilnya percepatan pertumbuhan ekonomi yang sudah direncanakan oleh pemerintah, serta tidak ditemukannya efisiensi proses bisnis pada bisnis mereka. Hal ini akan berujung kepada perekonomian Indonesia yang kurang bersaing dalam menghadapi persaingan bisnis secara global.

Tidak hanya itu masalah UMKM di kota Bandar Lampung juga mengalami kesulitan untuk melakukan pinjaman terkait biaya atau modal usaha karena untuk memenuhi persyaratan yang ditawarkan oleh pihak bank, biasanya prosedur yang harus dilalui cukup lama serta persyaratan dan jaminan masih sulit dipenuhi oleh pelaku usaha mikro, oleh karena itu dalam pengajuan kredit dibutuhkan prosedur yang tidak berbelit-belit dan mudah untuk dipenuhi, agar para pelaku usaha tidak kesulitan dalam memenuhi persyaratan yang ditetapkan terkait agunan dan persyaratan maupun yang lainnnya, sehingga dana pinjaman yang diajukan untuk memenuhi kebutuhan modal usaha dapat segera diperoleh dan digunakan untuk menjalankan usahanya. Dengan melihat permasalahan yang dihadapi oleh sektor UMKM di kota Bandar Lampung dalam hal permodalan, serta mengingat bagaimana pentingnya UMKM di kota Bandar Lampung terhadap perekonomian nasional, dibutuhkan peran pemerintah untuk mengadakan kebijakan ekonomi terkait pemberdayaan UMKM di kota Bandar Lampung terutama berupa bantuan kredit usaha dengan beban kredit yang ringan dan prosedur yang mudah. UMKM yang ada di Kota Bandar Lampung tahun 2018 sebanyak 2.125 UMKM. Sehingga, berdasarkan uraian latar belakang tersebut, maka peneliti tertarik melakukan penelitian terkait pengaruh literasi keuangan terhadap inklusi keuangan melalui financial technology pada UMKM di Bandar Lampung.

\section{Landasan Teori \\ Inklusi Keuangan}

Keuangan inklusif menjadi tren setelah terjadinya krisis tahun 2008 yang ditandai dengan banyaknya dampak yang terjadi pada golongan berpendapatan rendah, tinggal di daerah terpencil, orang cacat, buruh yang tidak mempunyai identitas legal dan masyarakat pinggiran. Inklusi keuangan merupakan keadaan di mana kurangnya jumlah masyarakat yang memiliki akses perbankan. Masyarakat lebih cendrung mengandalkan kepemilikan atas benda tidak bergerak yang mereka miliki untuk dapat digunakan dan dapat diuangkan sehari hari. Benda bergerak tersebut dapat diuangkan sewaktu-waktu untuk menyelesaikan permasalahan dengan menguangkannya tetunya dengan memberikan bantuan tenaga dan binaan.

Otoritas Keuangan dalam hal ini Bank Indonesia (BI) dan Otoritas Jasa Keuangan (OJK) mencanangkan strategi nasional keuangan inklusif yang dijabarkan dalam 6 pilar yaitu: 1) edukasi keuangan, 2) fasilitas keuangan publik, 3) pemetaan informasi keuangan, 4) kebijakan atau peraturan pendukung, 5) fasilitas intermediasi dan distribusi, dan 6) perlingungan 
konsumen. (Hanik, 2018). Jika masyarakat sudah dapat mengakses produk dan layanan keuangan dengan mudah, maka masyarakat akan lebih produktif dan berdaya beli sehingga tujuan dari perumusan pilar-pilar strategi keuangan inklusif ini akan tercapai yaitu 1) Pemerataan pendapatan di seluruh wilayah Indonesia dari sabang sampai merauke, 2) Secara organik akan mengurangi tingkat kemiskinan di daerah, 3) akan tercipta sistem keuangan yang stabil.

\section{Literasi Keuangan}

The Association of Chartered Certified Accountants (2014) merumuskan bahwa konsep literasi keuangan mencakup pengetahuan mengenai konsep keuangan, kemampuan memahami komunikasi mengenai konsep keuangan, kecakapan mengelola keuangan pribadi/perusahaan dan kemampuan melakukan keputusan keuangan dalam situasi tertentu. Lusardi (2012) menyatakan bahwa literasi keuangan terdiri dari sejumlah kemampuan dan pengetahuan mengenai keuangan yang dimiliki oleh seseorang untuk mampu mengelola atau menggunakan sejumlah uang untuk meningkatkan taraf hidupnya. Literasi keuangan sangat terkait dengan perilaku, kebiasaan dan pengaruh dari faktor eksternal. Berdasarkan PISA 2012: Financial Literacy Assessment Framework (OECD INFE, 2012), dirumuskan bahwa literasi keuangan merupakan faktor yang fundamental untuk pertumbuhan ekonomi dan stabilitas keuangan. Hal ini akan berakibat pada kompetisi di industri yang menjadi sehat dan kompetisi akan mengedepankan inovasi dalam barang dan jasa yang ditawarkan ke konsumen.

\section{Financial Technology (FinTech)}

Perkembangan fintech di dunia sudah dimulai sejak tahun 1800-an dengan munculnya telegraph dan semakin berkembang pada tahun-tahun selanjutnya khususnya pada era digital saat ini. Tahun 1900-an mulai berkembang Automated Teller Machine (ATM), Clearing House, Internet Banking dan Paypal. Kemudian semakin berkembang dengan adanya Apple Pay, Samsung Pay, Smile to Pay (Alibaba) pada tahun 2000-an. (Zimmerman, 2016). Di Indonesia perkembangan fintech jenis pembayaran semakin berkembang pesat, baik yang diterbitkan oleh lembaga keuangan seperti unikQu, Tbank, Ecash maupun yang diterbitkan oleh start-up fintech seperti Go-Pay dan OVO. Menurut Otoritas Jasa Keuangan (2016), kelebihan dari fintech adalah: 1) Melayani masyarakat Indonesia yang belum dapat dilayani oleh industri keuangan tradisional dikarenakan ketatnya peraturan perbankan dan adanya keterbatasan industri perbankan tradisional dalam melayani masyarakat di daerah tertentu, 2) Menjadi alternatif pendanaan selain jasa industri keuangan tradisional di mana masyarakat memerlukan alternatif pembiayaan yang lebih demokratis dan transparan. Sedangkan kekurangan dari fintech adalah: 1) Fintech merupakan pihak yang tidak memiliki lisensi untuk memindahkan dana dan kurang mapan dalam menjalankan usahanya dengan modal yang besar, jika dibandingkan dengan bank. 2) Ada sebagaian perusahaan Fintech belum memiliki kantor fisik, dan kurangnya pengalaman dalam menjalankan prosedur terkait sistem keamanan dan itegritas produknya.

\section{Hipotesis Penelitian}

H1 : Diduga literasi keuangan berpengaruh signifikan terhadap inklusi keuangan.

$\mathrm{H} 2$ : Diduga literasi keuangan berpengaruh signifikan terhadap financial technology

H3 : Diduga financial technology berpengaruh signifikan terhadap inklusi keuangan.

H4 : Diduga literasi keuangan berpengaruh signifikan terhadap inklusi keuangan melalui financial technology.

\section{Metode Penelitian}

Jenis data yang digunakan dalam penelitian ini adalah data primer. Data primer adalah responden individu, kelompok focus serta internet juga dapat menjadi sumber data primer jika 
koesioner disebarkan melalui internet (Uma Sekaran, 2011). Teknik pengambilan sampel yang digunakan adalah Purposive Sampling yaitu pengambilan sampel dengan kriteria tertentu yang telah ditetapkan oleh peneliti. Sampel pada penelitian ini adalah UMKM di Kota Bandar Lampung sebanyak 2,125 pada tahun 2018. Penelitian menggunakan rumus penentuan ukuran sampel yang dinyatakan oleh Slovin dengan tingkat kesalahan $10 \%=0$. Maka sampel yang digunakan dalam penelitian ini adalah sejumlah 100 sampel. Alat analisis yang digunakan dalam penelitian itu, yaitu Analisis Jalur (path analysis) yang merupakan suatu teknik pengembangan dari regresi berganda yang digunakan untuk menguji besarnya sumbangan (kontribusi) yang ditunjukkan oleh koefisien jalur pada setiap diagram jalur dari hubungan kausal antar variabel (Paul Webley, 2010).

\section{Hasil dan Pembahasan}

Penelitian ini menggunakan analisis Smart PLS Ver.3. Model teoritis yang telah digambarkan pada diagram jalur sebelumnya akan dilakukan analisis berdasarkan data yang telah diperoleh. Berdasarkan nilai t- statistics dari suatu hubungan kausalitas dari hasil pengolahan yaitu sebagai berikut.

Tabel 1

Path Coefficients (Mean, STDEV, T-Values)

\begin{tabular}{lccccc}
\hline & $\begin{array}{c}\text { Original } \\
\text { Sampel }\end{array}$ & $\begin{array}{c}\text { Sample } \\
\text { Mean }\end{array}$ & STDEV & T & P \\
& Statistik & Value \\
\hline Literasi Keuangan -> Inklusi Keuangan & 0,739 & 0,761 & 0,055 & 13,440 & 0,000 \\
Literasi Keuangan -> Financial Teknologi & 0,263 & 0,272 & 0,105 & 2,514 & 0,014 \\
Financial Teknologi -> Inklusi Keuangan & 0,036 & 0,042 & 0,074 & 0,482 & 0,631 \\
Literasi Keuangan -> Inklusi Keuangan & 0,026 & 0,031 & 0,004 & 6,478 & 0,000 \\
Melalui Financial Teknologi & & & & &
\end{tabular}

Sumber : Data diolah, 2019

Berdasarkan tabel 1 menunjukan bahwa nilai perhitungan pada Literasi Keuangan (X) diperoleh nilai t hitung sebesar 13,440 sedangkan nilai t tabel dengan $\mathrm{dk}(\mathrm{dk}=100-2=98)$ adalah 1,662 jadi t hitung $(13,440)>\mathrm{t}$ tabel $(1,662)$, dan nilai sig $(0,000)<0,05$. maka H0 ditolak dan $\mathrm{H}_{1}$ diterima. Artinya Literasi Keuangan berpengaruh signifikan terhadap inklusi keuangan. Hal ini menunjukan bahwa semakin tinggi pengetahuan keuangan, semakin baik perilaku keuangan serta sikap keuangan seseorang akan meningkatkan penggunaan, pemanfaatan serta pemahaman produk dan layanan jasa keuangan. Hal ini diperkuat dengan jawaban responden yang memiliki nilai tertinggi terkait literasi keuangan dimana para UMKM di Kota Bandar Lampung sudah percaya dan juga paham mengenai investasi yang berupa tingkat pengembalian dan risiko investasi, sehingga para pelaku usaha UMKM ini dengan melakukan investasi sedini mungkin diharapkan dapat memberikan keuntungan bagi mereka dimasa depan.

Nilai perhitungan pada Literasi Keuangan (X) diperoleh nilai t hitung sebesar 2,514 sedangkan nilai t tabel dengan $\mathrm{dk}(\mathrm{dk}=100-2=98)$ adalah 1,662 jadi $\mathrm{t}$ hitung $(2,514)>\mathrm{t}$ tabel $(1,662)$, dan nilai sig $(0,014)<0,05$. maka $\mathrm{H} 0$ ditolak dan $\mathrm{H}_{1}$ diterima. Artinya Literasi Keuangan berpengaruh signifikan terhadap financial teknologi. Masyarakat UMKM yang telah mempunyai pengetahuan yang tinggi, dapat menggunakan layanan keuangan berbasis digital akan mendukung pencapaian implementasi keuangan inklusif oleh pemerintah. Hal ini diperkuat dengan jawaban responden yang memiliki nilai tertinggi terkait financial teknologi dimana para UMKM di Kota Bandar Lampung dalam proses pembayaran sudah ikut berpartisipasi menggunakan aplikasi Fintech seperti GOPAY, OVO, Link dll karena mereka menganggap proses pembayaran ini menjadi lebih mudah dan relatif cepat.

Nilai perhitungan pada Financial teknologi $(Z)$ diperoleh nilai t hitung sebesar 0,482 sedangkan nilai $\mathrm{t}$ tabel dengan $\mathrm{dk}(\mathrm{dk}=100-2=98)$ adalah 1,662 jadi $\mathrm{t}$ hitung $(0,482)<\mathrm{t}$ tabel $(1,662)$, dan nilai sig $(0,631)>0,05$. maka $\mathrm{HO}$ diterima dan $\mathrm{H}_{1}$ ditolak. Artinya Financial teknologi tidak berpengaruh signifikan terhadap inklusi keuangan. Hasil penelitian ini dapat 
menjelaskan bahwa semakin tinggi masyarakat yang menggunakan layanan keuangan berbasis digital ternyata tidak mendukung pencapaian implementasi keuangan inklusif oleh pemerintah. Hal ini diperkuat dengan jawaban responden yang memiliki nilai terendah terkait inklusi keuangan dimana para pelaku UMKM di Kota Bandar Lampung kurang percaya dengan layanan konsultasi pada produk pembayaran akan terjamin.

Nilai perhitungan pada Literasi Keuangan (X) diperoleh nilai t hitung sebesar 6,478 sedangkan nilai $\mathrm{t}$ tabel dengan $\mathrm{dk}(\mathrm{dk}=100-2=98)$ adalah 1,662 jadi $\mathrm{t}$ hitung $(6,478)>\mathrm{t}$ tabel $(1,662)$, dan nilai sig $(0,000)<0,05$. maka $\mathrm{H} 0$ ditolak dan $\mathrm{H}_{1}$ diterima. Artinya Literasi Keuangan berpengaruh signifikan terhadap Inklusi Keuangan melalui Financial Teknologi. Hal ini menunjukkan bahwa semakin tinggi pengetahuan keuangan, semakin baik perilaku keuangan serta sikap keuangan seseorang akan meningkatkan penggunaan, pemanfaatan serta pemahaman produk dan layanan jasa keuangan.

\section{Kesimpulan}

Berdasarkan hasil analisis data dan pembahasan yang telah dilakukan untuk menjawab rumusan masalah penelitian, dapat disimpulkan bahwa :

1. Literasi keuangan berpengaruh sigifikan terhadap inklusi keuangan pada UMKM di Bandar Lampung.

2. Literasi keuangan berpengaruh sigifikan terhadap financial teknologi pada UMKM di Bandar Lampung.

3. Financial teknologi tidak berpengaruh sigifikan terhadap inklusi keuangan pada UMKM di Bandar Lampung.

4. Literasi keuangan berpengaruh sigifikan terhadap inklusi keuangan melalui financial teknologi pada UMKM di Bandar Lampung.

\section{Daftar Pustaka}

Dwitya, Aribawa. Pengaruh Literasi Keuangan Terhadap Kinerja Dan Keberlangsungan Umkm Di Jawa Tengah. Jurnal Siasat Bisnis Vol. 20 No. 1, Januari 2016

Fahlefi, Rizal. Inklusi Keuangan Syariah Melalui Inovasi Fintech Di Sektor Filantropi. Batusangkar International Conference III, October 15-16, 2018

Hanik, Fitriani. Kontribusi Fintech Dalam Meningkatkan Keuangan Inklusif Pada Pertanian (Studi Analisis Melalui Pendekatan Keuangan Syariah Dengan Situs Peer To Peer Lending Pada Pertanian Di Indonesia). el Barka: Journal of Islamic Economics and Business Volume 01, No. 01 Januari - Juni 2018

Irfan dan Aam. 2019. Digitalisasi Keuangan Syariah Menuju Keuangan Inklusif: Kerangka Maqashid Syariah. Ekspansi: Jurnal Ekonomi, Keuangan, Perbankan dan Akuntansi ISSN (Online): 2580-7668 ISSN (Print): 2085-5230 Vol. 11, No. 1 (Mei 2019), Hal. 55 $-76$

Kam Soetiono, K.S. Financial Literacy in Indonesia and The National Strategy. Hongkong. Citi-FT Financial Times Education Summit.2013

Wicaksono, dkk. Pengembangan Model Bisnis Bank "X" Dalam Mendukung Inklusi Keuangan Menggunakan Kerangka Kerja Soft System Methodology (SSM). MIX: Jurnal Ilmiah Manajemen, Volume 9, No. 1, Februari 2019 